\title{
Analisis Pemahaman Konsep Fisika Peserta Didik dengan Instrumen Four-Tier Diagnotict Test
}

\author{
Yuni Sufiani $^{1}{ }^{*} *$ Erniwati $^{2)}$, Rosliana Eso ${ }^{3)}$ \\ 1)* Mahasiswa Jurusan Pendidikan Fisika, Universitas Halu Oleo, Indonesia \\ ${ }^{2), 3)}$ Dosen Jurusan Pendidikan Fisika, Universitas Halu Oleo, Indonesia \\ *Korespondensi Email: yunisufiani@gmail.com
}

\begin{abstract}
Abstrak: Penelitian ini bertujuan untuk mengetahui pemahaman konsep peserta didik pada materi gelombang mekanik bagi peserta didik di kelas XI SMAN 1 Mawasangka Tengah. Jenis penelitian ini merupakan jenis penelitian deskriptif kuantitatif. Dalam penelitian ini penulis ingin menganalisi pemahaman konsep peserta didik dengan menggunakan instrument Four-tier diagnostic test. Objek penelitian ini adalah peserta didik kelas XI IPA (1) dan XI IPA (2) di SMAN 1 Mawasangka Tengah.. Data dalam penelitian ini adalah data primer yang dikumpulkan dengan menggunakan soal Four-tier diagnostic test dan dokumentasi. Hasil analisis data diperoleh menunjukan bahwa nilai rata-rata presentase tingkat pemahaman peserta didik sub konsep (1) faktor-faktor yang mempengaruhi cepat rambat gelombang yaitu 4,4\% paham konsep, 81,4\% miskonsepsi dan $14,2 \%$ tidak paham konsep. (2) Periode gelombang berjalan yaitu 23,5\% paham konsep, 64,4\% miskonsepsi dan 13,1\% tidak paham konsep (3) Frekuensi gelombang berjalan yaitu 32,2\% paham konsep, 51,4\% miskonsepsi dan 16,4\% tidak paham konsep (4) Frekuensi pada gelombang stasioner yaitu 36,6\% paham konsep, 48,6\% miskonsepsi dan 14,7\% tidak paham konsep dan (5) Panjang gelombang pada gelombang stasioner yaitu $15,8 \%$ paham konsep, 69,9\% miskonsepsi dan $14,2 \%$ tidak paham konsep. Berdasarkan hasil analisis diperoleh kesimpulan bahwa: 1) Pemahaman konsep peserta didik pada materi Gelombang Mekanik termasuk dalam kategori rendah. Peserta didik yang paham konsep sebesar 22,5\%, sebagian besar pemahaman peserta didik pada kriteria tidak paham konsep sebesar14,7\% dan $62,8 \%$ terindikasi mengalami miskonsepsi. 2) Miskonsepsi kategori tinggi ditemukan pada konsep faktorfaktor yang mempengaruhi cepat rambat gelombang sebesar $81,4 \%$.
\end{abstract}

Kata Kunci: Pemahaman Konsep; Four-Tier Diagnotic Test; Gelombang.

Abstract: This study aims to determine the understanding of the concept of students on mechanical wave material for students in class XI SMAN 1 Mawasangka Tengah. This type of research is a type of quantitative descriptive research. In this study, the authors wanted to analyze the students' conceptual understanding using the Four-tier diagnostic test instrument. The object of this research is the students of class XI IPA (1) and XI IPA (2) at SMAN 1 Mawasangka Tengah. The data in this study are primary data collected using four-tier diagnostic tests and documentation. The results of the data analysis showed that the average value of the percentage level of understanding of sub-concept students (1) the factors that influence the speed of the wave propagation, namely $4.4 \%$ understanding the concept, $81.4 \%$ misconception and $14.2 \%$ not understanding the concept (2) The current wave period is $23.5 \%$ understanding the concept, $64.4 \%$ misconception and $13.1 \%$ not understanding the concept (3) The frequency of the traveling wave is $32.2 \%$ understanding the concept, $51.4 \%$ misconception and $16.4 \%$ do not understand the concept (4) Frequency on stationary waves is $36.6 \%$ understand the concept, $48.6 \%$ misconception and $14.7 \%$ do not understand the concept and (5) Wavelength on stationary waves is $15.8 \%$ understand the concept, 69, 9\% had misconceptions and 14.2\% did not understand the concept. Based on the results of the analysis, it was concluded that: 1) The students' understanding of the concept of mechanical waves was included in the low category. Students who understood the concept were $22.5 \%$, most of the students' understanding of the criteria did not understand the concept of $14.7 \%$ and $62.8 \%$ indicated that they had misconceptions. 2) Misconception of the high category found in the concept of factors that affect the speed of wave propagation by $81.4 \%$.

Keywords: Concept Understanding; Four-Tier Diagnotic Test; Wave 


\section{PENDAHULUAN}

Setiap konsep dalam pembelajaran fisika tidak berdiri sendiri, melainkan berhubungan dengan konsep-konsep yang lain. Semua konsep bersama membentuk semacam jaringan pengetahuan di dalam pikiran manusia. Namun seringkali para siswa hanya menghafalkan rumus dan definisi dari konsep fisika tanpa disertai pemahaman konsep yang baik dan tidak memperhatikan hubungan antara satu konsep dengan konsep-konsep lainnya (Khairunnisa, 2020). Kesalahan siswa dalam memahami hubungan antar konsep seringkali menimbulkan miskonsepsi (Iriyanti, 2012).

Miskonsepsi menurut Widyanto, dkk (2018) adalah suatu konsepsi yang diyakini kuat dan merupakan suatu struktur kognitif yang melekat dengan kuat dan stabil dibenak peserta didik yang sebenarnya menyimpang dari konsepsi yang dikemukakan para ahli. Miskonsepsi yang dialami oleh peserta didik akan menghambat proses penerimaan pemahaman konsep baru. Miskonsepsi dalam semua bidang fisika. Dari 700 studi mengenai miskonsepsi bidang fisika, ada 300 yang meneliti tentang miskonsepsi dalam mekanika merupakan jumlah tertinggi (Suparno, 2013). Cukup jelas bahwa bidang mekanika berada di urutan teratas dari bidang-bidang fisika yang mengalami miskonsepsi. Materi gelombang merupakan salah satu cabang mekanika yang harus dikuasai dalam pembelajaran. Secara umum, miskonsepsi dapat disebabkan oleh beberapa faktor, seperti dari kemampuan siswa, guru, buku teks, cara mengajar dan beberapa konteks tertentu yang berasal dari kehidupan siswa (Suparno, 2005).

Dari observasi yang dilakukan di SMA Negeri 1 Mawasangka Tengah di peroleh informasi bahwa guru lebih menitikberatkan agar peserta didik dapat hafal rumus dan dapat mengerjakan banyak soal. Guru lebih sering menyampaikan rumus-rumus cepat untuk menyelesaikan soal hitungan tanpa menyampaikan fenomena yang terkait. Selama ini belum ada upaya yang dilakukan oleh guru untuk mengungkap miskonsepsi yang dialami peserta didik sebelum dan selama pembelajaran di kelas, sehingga bisa saja peserta didik memiliki prakonsep yang keliru yang tidak di ketahui oleh guru. Dari beberapa mata pelajaran fisika yang sulit dipahami konsepnya adalah gelombang mekanik.

Hasil penelitian terdahulu mengenai miskonsepsi pada materi gelombang mekanik yang telah dilakukan Susanti (2014) didasarkan pada studi literature tentang gelombang dan getaran peserta didik menganggap bahwa: (1) kelajuan rambat bunyi hanya dipengaruhi oleh medium $(56,45 \%)$; (2) pada medium yang sama, semakin besar amplitudo maka laju rambat gelombang semakin besar $(45,16 \%)$; (3) selama menjalar dari satu tempat ke tempat yang lain, gelombang akan memindahkan partikel (40,32 $\%)$; (4) gelombang bunyi termasuk jenis gelombang transversal (40,32 \%); (40,32 \%); (5) ketika frekuensi ditingkatkan, maka panjang gelombang memanjang dan kecepatan gelombang tetap $(33,87$ $\%$ ). Berdasarkan hasil penelitian Na'imatul Istiqoma (2017) mengatakan presentase rata-rata siswa yang mengalami miskonsepsi pada pembelajaran gelombang mekanik adalah $14,14 \%$, dimana miskonsepsi yang di alami dalam kategori rendah. Selanjutnya penelitian yang dilakukan Widiyanto, dkk (2018) menyatakan bahwa Pemahaman konsep peserta didik MA Darul 'Ulum Sumberpenganten Jogoroto Jombang pada materi Gelombang Mekanik termasuk dalam kategori lemah dengan kategori lemah rata-rata sebesar $64,6 \%$, dan banyak pula yang mengalami kategori miskonsepsi dengan rata-rata sebesar $26,9 \%$.

Miskonsepsi yang dialami peserta didik harus segera diatasi. Salah satunya dengan memberikan instrument penilaian untuk mengetahui pemahaman konsep peserta didik. Dari bermacam model-model penilaian, peneliti menggunakan penilaian diagnostik untuk menyelesaikan miskonsepsi yang dialami oleh peserta didik. Adapun alasan pemilihan penilaian diagnostik adalah karena model penilian diagnosistik sangat relevan dan cocok sebagai penilaian dari analisis pemahaman konsep peserta didik sekarang.

Pentingnya analisis pemahaman konsep gelombang mekanik adalah bertujuan untuk menganalisis jenis kesalahan peserta didik dalam memahami konsep materi gelombang mekanik dan mengetahui pemahaman konsep peserta didik pada materi gelombang mekanik tersebut. Analisis ini dapat juga digunakan untuk mengetahui persebaran pemahaman konsep peserta didik tentang matari gelombang mekanik. Analisis pemahaman konsep yang digunakan pada penelitihan ini menggunakan Instrument Fout Tier Diagnostic Test. Pemilihan instrument Four Tier Diagnosis Test (FTDT) karena di asumsikan mampu mengatasi permasalahan peseta didik, terutama dalam pemahaman konsep. Permasalahn yang akan dikaji pada penelitian ini adalah (1) Bagaimana pemahaman konsep pada materi gelombang mekanik bagi peserta didik di SMAN 1 Mawasangka Tengah ?;(2).Bagamanakah tingkat miskonsepsi yang terjadi berdasarkan sub konsep?. Tujuan dari kajian ini adalah untuk 
menganalisa pemahaman konsep dan miskonsepsi peserta didik khususnya pada pelajaran Fisika.

\section{METODE}

Jenis penelitian ini merupakan jenis penelitian deskriptif kuantitatif. Populasi dalam penelitian ini adalah keseluruhan kelas XI IPA SMAN 1 Mawasangka Tengah berjumlah 61 peserta didik. Seluruh populasi dijadikan sampel dalam penelitian. Teknik pengumpulan data terdiri dari tes dan dokumentasi. Tes yang akan digunakan adalah tes obyektif berbentuk pilihan ganda berjumlah 15 soal. Tes dilakukan untuk mengetahui tinggi rendahnya pemahaman konsep peserta didik pada materi gelombang mekanik bagi peserta didik di kelas XI SMAN 1 Mawasangka Tengah. Penelitian ini menggunakan instrumen penelitian Four Tier Diagnostic Test untuk materi Gelombang dengan

$$
P=\frac{f}{N} x 100 \%
$$

Dengan: $P=$ angka persentase kelompok, $f=$ jumlah peserta didik tiap kelompok, $N=$ jumlah individu (jumlah seluruh peserta didik yang menjadi subjek penelitian). fokus pada sub materi Gelombang Mekanik. Fourtier diagnostic test memiliki empat tingakatan: a) tingkat pertama untuk soal pengetahuan dalam bentuk pilihan ganda dengan empat pilihan jawaban, b) tingkat kedua berisi tingkat keyakinan atas jawaban terhadap tingkat pertama, c) tingkat ketiga berisi alasan jawaban pada tingkat pertama dengan empat pilihan alasan dan d) tingkat keempat berisi tingkat keyakinan atas alasan jawaban pada tingkat ketiga.

Teknik analisis yang digunakan adalah analisis deskriptif persentase. Tahap I : Mendata jawaban siswa disetiap butir soal ke dalam 4 kategori yaitu paham konsep, miskonsepsi, tidak paham konsep, dan menebak. Tahap II : Menghitung persentase jawaban siswa tiap kategori dengan menggunakan persamaan (1).

Tabel 1 .Persentase Miskonsepsi

\begin{tabular}{ccl}
\hline No & Persentase Miskonsepsi & \multicolumn{1}{c}{ Kategori } \\
\hline 1 & $86-100 \%$ & Sangat tinggi \\
2 & $76-85 \%$ & Tinggi \\
3 & $60-75 \%$ & Sedang \\
4 & $55-59 \%$ & Rendah \\
5 & $\leq 54 \%$ & Sangat rendah \\
\hline
\end{tabular}

HASIL PENELITIAN

1. Persentase Jawaban hasil Tes Diagnotisk Four-Tier Test
Presentase jawaban hasil tes diagnostik four-tier test siswa SMAN 1 Mawasasangka Tengah pada materi gelombang mekanik dapat dilihat pada Tabel 2.

Tabel 2. Presentase jawaban hasil tes diagnostik four-tier test.

\begin{tabular}{|c|c|c|c|c|c|c|c|c|c|}
\hline \multirow{3}{*}{$\begin{array}{c}\text { No } \\
\text { soal }\end{array}$} & \multicolumn{6}{|c|}{ Jumlah peserta didik } & \multirow{2}{*}{\multicolumn{3}{|c|}{$\begin{array}{c}\text { Presentase tingkat pemahaman } \\
\text { peserta didik } \\
\text { Presentase \% }\end{array}$}} \\
\hline & \multicolumn{3}{|c|}{ XI IPA /1 } & \multicolumn{3}{|c|}{ XI IPA /2 } & & & \\
\hline & PK & $\mathbf{M}$ & TPK & PK & $\mathbf{M}$ & TPK & PK & $\mathbf{M}$ & TPK \\
\hline 1 & 4 & 24 & 2 & 1 & 24 & 6 & 8,2 & 78,69 & 13,11 \\
\hline 2 & 1 & 25 & 4 & 1 & 25 & 5 & 3,28 & 81,97 & 14,75 \\
\hline 3 & 0 & 24 & 6 & 1 & 27 & 3 & 1,63 & 83.60 & 14,75 \\
\hline 4 & 10 & 15 & 5 & 6 & 22 & 3 & 26,23 & 60,66 & 13,11 \\
\hline 5 & 4 & 21 & 5 & 4 & 24 & 3 & 13,11 & 73,77 & 13,11 \\
\hline 6 & 13 & 13 & 4 & 6 & 21 & 4 & 31,15 & 55,74 & 22,95 \\
\hline 7 & 10 & 15 & 5 & 7 & 19 & 5 & 27,87 & 55,74 & 16,39 \\
\hline
\end{tabular}




\begin{tabular}{cccccccccc}
\hline & \multicolumn{4}{c}{ Jumlah peserta didik } & \multicolumn{3}{c}{$\begin{array}{c}\text { Presentase tingkat pemahaman } \\
\text { No } \\
\text { Noal }\end{array}$} & \multicolumn{4}{c}{ Pearta didik } \\
\cline { 2 - 10 } & \multicolumn{3}{c}{ XI IPA /1 } & \multicolumn{3}{c}{ XI IPA /2 } & \multicolumn{3}{c}{ Presentase \% } \\
\cline { 2 - 10 } & PK & M & TPK & PK & M & TPK & PK & M & TPK \\
\hline 8 & 14 & 11 & 5 & 7 & 18 & 6 & 34,43 & 47,54 & 18,03 \\
9 & 15 & 10 & 5 & 6 & 21 & 4 & 34,43 & 50,82 & 14,75 \\
10 & 14 & 13 & 3 & 14 & 16 & 1 & 45,90 & 47,54 & 6,56 \\
11 & 11 & 13 & 6 & 5 & 22 & 4 & 26,23 & 57,38 & 16,39 \\
12 & 9 & 12 & 9 & 14 & 13 & 4 & 37,70 & 40,98 & 21,31 \\
13 & 4 & 18 & 8 & 2 & 26 & 3 & 9,84 & 72,13 & 18,03 \\
14 & 8 & 17 & 5 & 5 & 22 & 4 & 21,31 & 63,93 & 14,75 \\
15 & 8 & 19 & 3 & 2 & 26 & 3 & 16,39 & 73,77 & 9,83 \\
\hline
\end{tabular}

Berdsarkan data hasil tes diagnostik pada Tabel 2 dengan soal four-tier test diketahui bahwa dari 15 nomor soal yang di berikan kepada 61 peserta didik, sebesar 62,8\% masih mengalami miskonsepsi pada konsep gelombang mekanik terlihat dari masingmasing presentase dimana presentase paham konsep maupun tidak paham konsep sangat renda

2. Presentase Rata-rata Jawaban Diagnostik Four-Tier Test Peserta Didik Berdasarkan Sub Konsep Faktor-Faktor Yang Mempengaruhi
Cepat Rambat Gelombang, Periode Gelombang Berjalan, Frekuensi Gelombang Berjalan, Frekuensi Pada Gelombang Stasioner, Dan Panjang Gelombang Pada Gelombang Stasioner

Presentase rata-rata jawaban tes diagnostik fourtier test peserta didik kelas XI IPA (1) dan XI IPA (2) SMAN 1 Mawsangka Tengah berdasarkan masing-masing sub konsep dapat dilihat pada Tabel 3.

Tabel 3. Presentase rata-rata jawaban diagnostik four tier test peserta didik berdasarkan sub konsep

\begin{tabular}{lccccccc}
\hline \multicolumn{1}{c}{ Sub-sub konsep } & No & \multicolumn{2}{c}{ Jumlah } & peserta didik & \multicolumn{3}{c}{ Presentase sub konsep } \\
\cline { 2 - 8 } & Soal & PK & M & TPK & PK\% & M\% & TPK\% \\
\hline Faktor-faktor yang mempengaruhi cepat & 1 & 5 & 48 & 8 & 8,2 & 78,69 & 13,11 \\
rambat gelombang & 2 & 2 & 50 & 9 & 3,28 & 81,97 & 14,75 \\
& 3 & 1 & 51 & 9 & 1,63 & 83.60 & 14,75 \\
\hline Periode gelombang berjalan & 4 & 16 & 37 & 8 & 26,23 & 60,66 & 13,11 \\
& 5 & 8 & 45 & 8 & 13,11 & 73,77 & 13,11 \\
& 6 & 19 & 34 & 8 & 31,15 & 55,74 & 13,11 \\
\hline Frekuensi gelombang berjalan & 7 & 17 & 34 & 10 & 27,87 & 55,74 & 16,39 \\
& 8 & 21 & 29 & 11 & 34,43 & 47,54 & 18,03 \\
& 9 & 21 & 31 & 9 & 34,43 & 50,82 & 14,75 \\
\hline Frekuensi pada gelombang stasioner & 10 & 28 & 29 & 4 & 45,90 & 47,54 & 6,56 \\
& 11 & 16 & 35 & 10 & 26,23 & 57,38 & 16,39 \\
& 12 & 23 & 25 & 13 & 37,70 & 40,98 & 21,31 \\
\hline Panjang gelombang pada gelombang & 13 & 6 & 44 & 11 & 9,8 & 72,13 & 18,03 \\
stasioner & 14 & 13 & 39 & 9 & 21,31 & 63,93 & 14,75 \\
& 15 & 10 & 45 & 6 & 16,39 & 73,77 & 9,83 \\
\hline
\end{tabular}


3. Presentase Tingkat Pemahaman Peserta Didik Sub Konsep Faktor-Faktor yang Mempengaruhi Cepat Rambat Gelombang, Periode Gelombang Berjalan, Frekuensi Gelombang Berjalan, Frekuensi pada

Gelombang Stasioner, dan Panjang Gelombang pada Gelombang Stasioner

Presentase tingkat pemahan konsep peserta didik untuk masing-masing sub-konsep dapat dilihat pada Gambar 1.

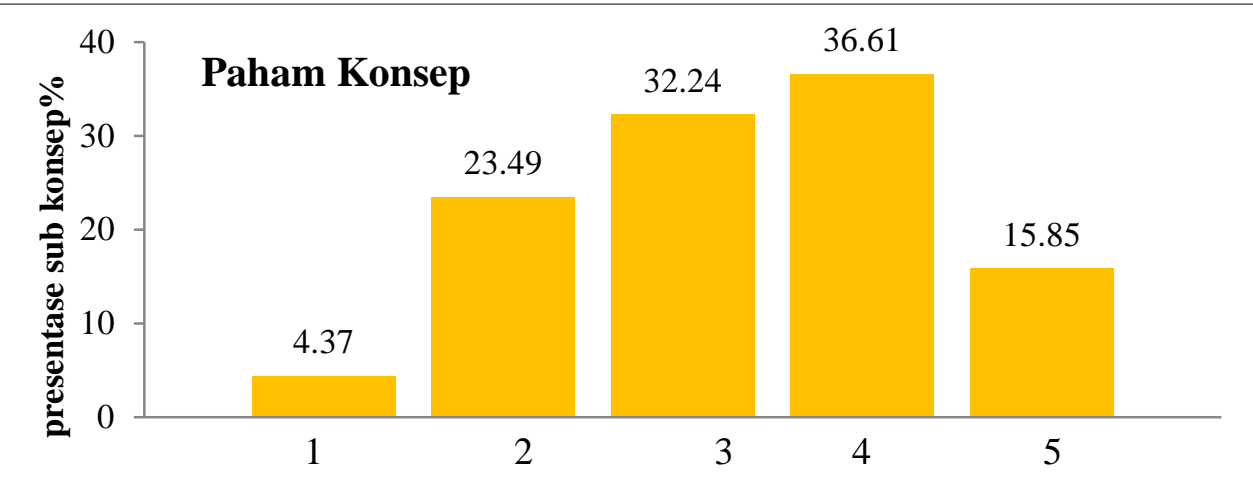

Gambar . Presentase tingkat pemahaman peserta didik sub konsep (1) faktor-faktor yang mempengaruhi cepat rambat gelombang, (2) Periode gelombang berjalan, (3) Frekuensi gelombang berjalan, (4) Frekuensi pada gelombang stasioner, dan (5) Panjang gelombang pada gelombang stasioner

Berdasarkan Gambar 4 terlihat bahwa presentase tingkat pemahaman peserta didik yang paling tinggi terdapat pada materi frekuensi pada gelombang stasioner yaitu $36,6 \%$. Selanjutnya disusul materi frekuensi gelombang berjalan dengan selisi yaitu $4,4 \%$. Kemudian disusul materi periode gelombang berjalan dengan selisi $13,2 \%$. Selanjutnya materi Panjang gelombang pada gelombang stasioner dengan selisi yaitu 20,2\%. Dan terakhir materi faktor-faktor yang mempengaruhi cepat rambat gelombang dengan selisi yaitu $31,9 \%$.
4. Presentase Tingkat Miskonsepsi Peserta Didik Sub-Konsep Faktor-Faktor Yang Mempengaruhi Cepat Rambat Gelombang, Periode Gelombang Berjalan, Frekuensi Gelombang Berjalan, Frekuensi pada Gelombang Stasioner, Dan Panjang Gelombang pada Gelombang Stasioner

Presentase tingkat miskonsepsi peserta didik untuk masing-masing sub-konsep dapat dilihat pada Gambar 2.

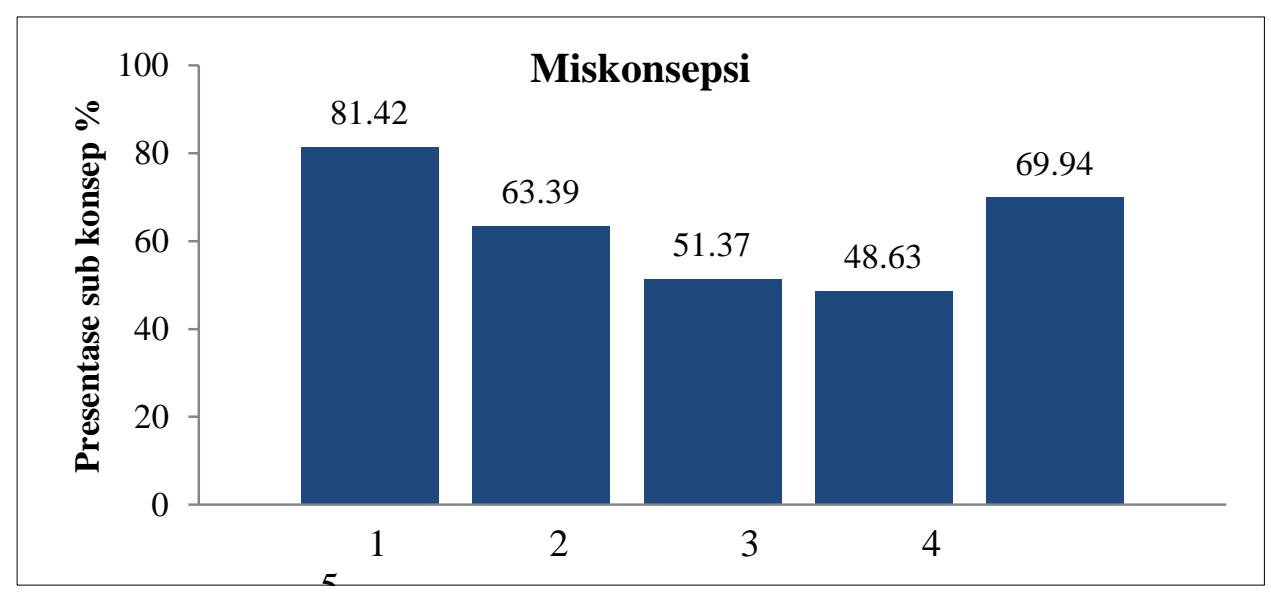

Gambar 2. Presentase tingkat miskonsepsi peserta didik sub-konsep (1) faktor-faktor yang mempengaruhi cepat rambat gelombang, (2) Periode gelombang berjalan, (3) Frekuensi gelombang berjalan, (4) Frekuensi pada gelombang stasioner, dan (5) Panjang gelombang pada gelombang stasioner 
Berdasarkan Gambar 2 menginterprestasikan bahwa presentase tingkat pemahaman peserta didik yang paling tinggi terdapat pada materi faktor-faktor yang mempengaruhi cepat rambat gelombang yaitu $81,4 \%$. Selanjutnya disusul materi panjang gelombang pada gelombang stasioner dengan selisi yaitu $11,5 \%$. Kemudian disusul materi periode gelombang berjalan dengan selisi $18,1 \%$. Selanjutnya materi frekuensi gelombang berjalan dengan selisi yaitu 30,1\%. Dan terakhir materi frekuensi pada gelombang stasioner dengan selisi yaitu $32,8 \%$.
5. Presentase Tingkat Tidak Pemahan Konsep Peserta Didik Sub Konsep Faktor-Faktor Yang Mempengaruhi Cepat Rambat Gelombang, Periode Gelombang Berjalan, Frekuensi Gelombang Berjalan, Frekuensi pada Gelombang Stasioner, Dan Panjang Gelombang pada Gelombang Stasioner

Presentase tingkat tidak paham konsep peserta didik untuk masing-masing sub-konsep dapat dilihat pada Gambar 3

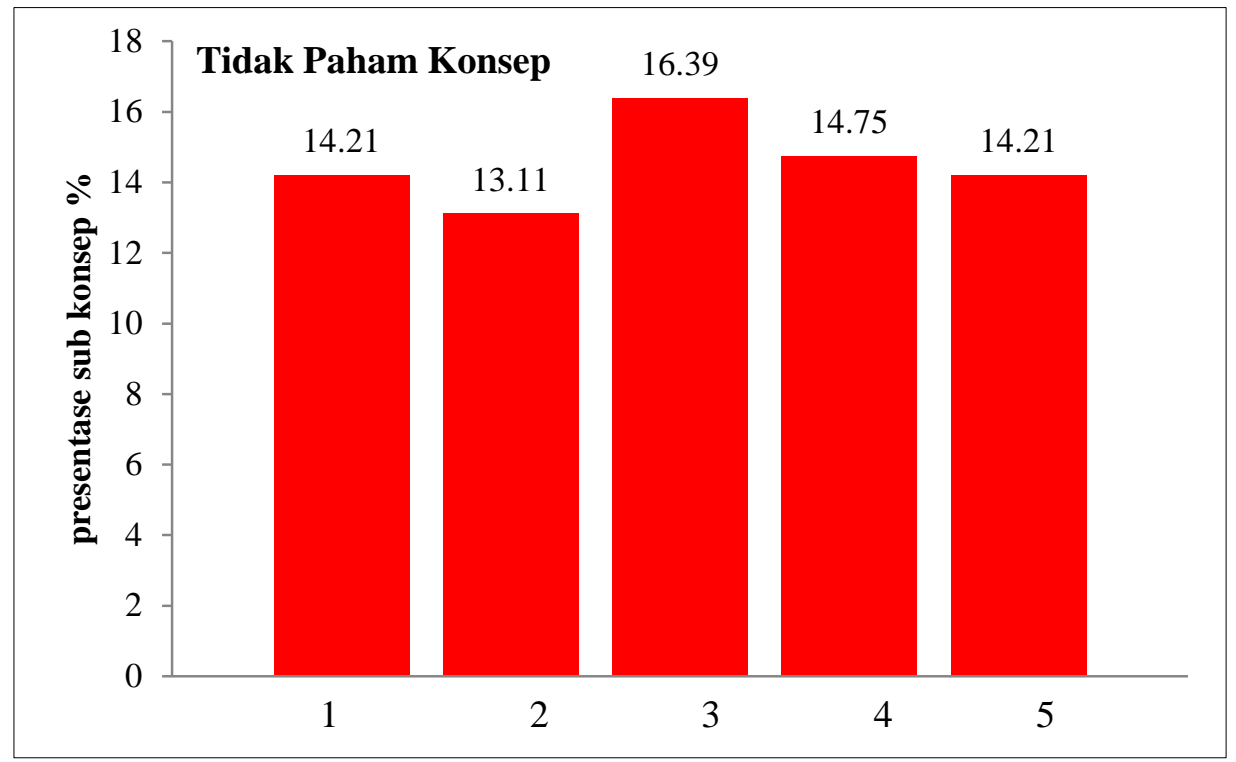

Gambar 3. Presentase tingkat tidak paham konsep peserta didik sub-konsep (1) faktor-faktor yang mempengaruhi cepat rambat gelombang, (2) Periode gelombang berjalan, (3) Frekuensi gelombang berjalan, (4) Frekuensi pada gelombang stasioner, dan (5) Panjang gelombang pada gelombang stasioner

Dari Ganbar 3 menunjukan bahwa presentase tingkat pemahaman peserta didik yang paling tinggi terdapat pada materi frekuensi gelombang berjalan yaitu 16,3\%. Selanjutnya disusul materi Frekuensi pada gelombang stasioner dengan selisi yaitu $1,6 \%$. Kemudian disusul materi faktor-faktor yang mempengaruhi cepat rambat gelombang dan sama dengan materi Panjang gelombang pada gelombang stasioner dengan selisi $2,1 \%$. Dan selanjutnya materi periode gelombang berjalan dengan $3,2 \%$.

\section{Persentase Miskonsepsi untuk Masing- masing Tipe}

Persentase tingkat miskonsepsi berdasarkan masing-masing tipe dapat disajikan pada Gambar 4. 


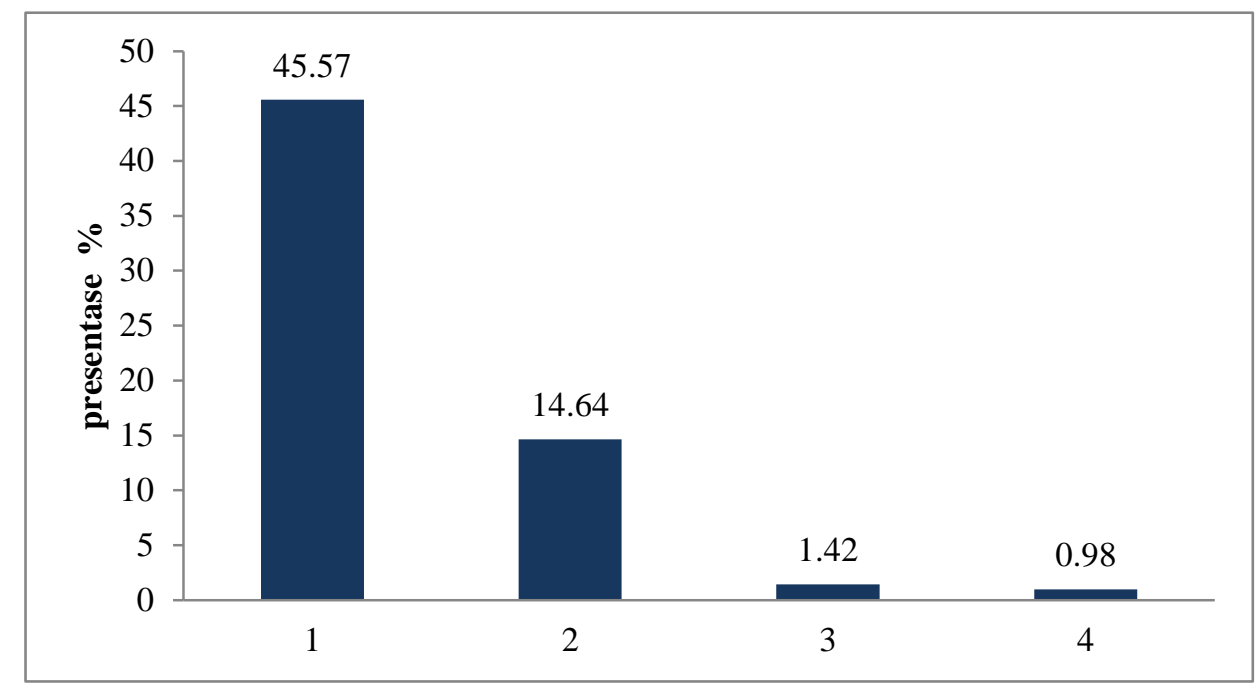

Gambar 4. Presentase Miskonsepsi Siswa Untuk Masing-Masing Tipe

1. SYSY : Salah -Yakin- Salah-Yakin

2. BYSY : Benar-Yakin- Salah-Yakin

3. STSY : Salah-Tidak Yakin- Salah-Yakin

4. BTSY : Benar-Tidak Yakin- Salah-Yakin

Hasil analisis menujukkan bahwa Gambar 4 didik yang mengalami miskonsepsi banyak yang memilih kategori salah-yakin-salah-yakin dengan nilai $45,57 \%$. Selanjutnya peserta didik memilih kategori jawaban benar- yakin-salah-yakin dengan selisih nilai yaitu $30,93 \%$. Kemudian peserta didik memilih kategori jawaban salah- tidak yakin-salahyakin dengan selisih nilai yaitu 44,15\%. Dan terakhir peserta didik memilih kategori jawaban benar- tidak yakin-salah-yakin dengan selisih nilai yaitu $44,57 \%$.

\section{PEMBAHASAN}

Analisis penelitian ini dilakukan untuk mengukur tingkat pemahaman konsep peserta didik setelah di peroleh informasi dalam pembelajaran . Penelitian yang telah dilakukan dengan instrument four-tier test pilihan ganda, kemudian dikelompokkan dalam kategori tingkat pemahaman berdasarkan pola jawaban, yaitu paham konsep, miskonsepsi dan tidak paham konsep dari 15 butir soal yang diujikan. Setelah dilakukan penelitian, hasil tes diagnostik four-tier test peserta didik SMAN 1 Mawasasangka Tengah untuk tingkat pemahaman konsep pada materi gelombang mekanik secara keseluruhan masi rendah. Terlihat dari persentase rata-rata tiap kategori dimana untuk pemahaman konsep memiliki presentase sebesar
22,5\%. Selanjutnya peserta didik untuk kategori yang tidak paham konsep sebesar 14,5\%. Justru persentase yang tinggi diperoleh untuk kategori miskonsepsi dimana persentase yaitu $62,8 \%$. Berdasarkan butir soal tes diagnostik four-tier test untuk menilai pemahaman konsep peserta didik dalam penelitian ini terbagi dalam lima sub konsep.

Untuk sub konsep ini terdapat pada soal no. 1, 2 dan 3. Jika dilihat dari pola jawaban peserta didik, pemahaman yang dimiliki masih sangat rendah dan termaksut dalam kategori miskonsepsi tinggi. Berdasarkan hasil analisis tampak bahwa hanya $4,37 \%$ peserta didik yang memiliki kriteria paham tentang faktor-faktor yang mempengaruhi cepat rambat gelombang. Sebagian besar pemahaman peserta didik dalam kriteria tidak paham $14,2 \%$ dan $81,42 \%$ peserta didik terindikasi mengalami miskonsepsi. Hal itu disebabkan karena mereka beranggapan bahwa untuk mengubah kecepatan gelombang itu dengan mengubah frekuensi gelombang pada tali. Hasil wawancara peserta didik mereka berfikir bahwa dengan menggerakkan tangan lebih cepat maka akan meningkatkan frekuensi. Yustiandi \& Saepuzaman (2017) menunjukan kelemahan dalam menentukan faktor-faktor yang mempengaruhi cepat rambat gelombang tingkat miskonsepsinya sangat tinngi.

Dari aspek pemahaman konsep periode gelombang berjalan terlihat bahwa untuk sub 
konsep ini tersebar pada item soal no. 4, 5 dan 6 . Jika dilihat dari pola jawabannya, peserta didik mengalami miskonsepsi kategori sedang. Berdasarkan hasil analisis tampak bahwa hanya $23,49 \%$ peserta didik yang paham konsep, miskonsepsi sebesar $63,38 \%$ dan tidak paham konsep sebesar $13,11 \%$. Hal ini disebabkan kebanyakan dari mereka belum mampu mendefinisikan konsep dari satu periode gelombang berjalan. Mereka beranggapan bahwa periode merupakan jarak yang ditempuh oleh gelombang dalam satu gelombang.

Hasil ini didukung dari hasil wawancara yang diperoleh bahwa bahwa mereka sering keliru dengan defenisi konsep kecepatan gelombang dengan periede gelombang. Berdasarkan (Tiara, 2018), periode $(T)$ adalah waktu yang diperlukan untuk menempuh jarak sepanjang satu panjang gelombang. Kecepatan gelombang (v) adalah jarak yang ditempuh gelombang dalam satu satuan waktu. Waluya (2008) juga mengatakan pemahaman konsep adalah kemampuan menangkap pengertianpengertian seperti mampu mengungkapkan suatu materi yang disajikan ke dalam bentuk yang lebih dipahami (Translasi), mampu memberikan interpretasi, dan mampu mengaplikasikannya (Ekstrapolasi). Dalam pemahaman konsep, siswa tidak hanya sebatas mengenal, tetapi siswa harus dapat menghubungkan satu konsep dengan konsep lain.. Selain itu, pada konsep frekuensi gelombang berjalan pola jawaban peserta didik miskonsepsi yang dialami termaksut kategori sangat rendah. Berdasarkan hasil analisis tampak bahwa ada $32,24 \%$ peserta didik yang memiliki kriteria paham konsep. Sebagian besar pemahaman peserta didik dalam kriteria tidak paham konsep $16,39 \%$ dan $51,36 \%$ peserta didik terindikasi mengalami miskonsepsi. Berdasarkan hasil dapat disimpulkan bahwa peserta didik sudah bisa memahami menyelesaikan soal perbandingan frekuensi gelombang berjalan.

Berbeda halnya dengan konsep frekuensi pada gelombang stasioner persentase jumlah siswa yang mengalami miskonsepsi sebesar 48,63\%. Miskonsepsi yang dialami peserta didik termaksut kategori paling rendah dibandingkan dengan sub konsep lainnya artinya dalam konsep ini peserta didik sudah bisa memahami konsep tentang frekuensi pada gelombang stasioner. Pemahaman konsep adalah kondisi dimana respon yang diberikan oleh peserta didik meliputi semua komponen yang diinginkan dan mereka yakin dengan jawaban beserta alasan yang diberikan. Peserta didik pada kondisi ini dianggap telah menguasai materi atau konsep yang diberikan dengan baik (Abraham, dkk. 1992) dan dapat membedakan apa yang mereka ketahui dan apa yang tidak mereka ketahui (McClary \& Bretz, 2012). Hal serupa ditemui pada konsep panjang gelombang pada gelombang stasioner yaitu persentase siswa yang mengalami miskonsepsi terjadi sebesar $69,94 \%$. Dari pola jawaban peserta didik miskonsepsi kategori sedang, hal ini disebabkan karena banyak dari mereka yang menjawab salah mereka belum bisa menjawab perubahan panjang gelombang dari gelombang berdiri harmonis ketika diberikan beban. Data ini diperkuat dari hasil wawancara bahwa banyak siswa tidak mengerti dengan percobaan melde yang dikarenakan jarang sekali melakukan percobaan melde.

Miskonsepsi kategori tinggi ditemukan pada konsep faktor-faktor yang mempengaruhi cepat rambat gelombang. Miskonsepsi kategori sedang ditemukan pada konsep periode gelombang berjalan dan Panjang gelombang pada gelombang stasioner. Sedangkan miskonsepsi kategori rendah ditemukan pada sub konsep frekuensi gelombang berjalan dan frekuensi pada gelombang stasioner. Kebanyakan peserta didik yang mengalami miskonsepsi memilih dua opsi jawaban yang berbeda. Jawaban yang pertama peserta didik memilih jawaban salah pada tingkat pertama dengan alasan salah pada tingkat ke tiga tapi yakin akan jawaban pada tingkat ke dua dan ke empat. Ada juga yang memilih jawaban benar pada tingkat pertama, yakin pada tingkat kedua, salah tingkat ke tiga tapi yakin pada alasan pada tingkat ke empat. Kategori ini sesuai dengan (Abraham, 1992) Miskonsepsi adalah kondisi dimana respon yang diberikan oleh peserta didik benar pada muatan konsep yang ditanyakan namun tidak dapat memberikan alasan saintifik yang tepat untuk menguatkan konsep yang dimilikinya. Miskonsepsi positif juga dapat diartikan bahwa peserta didik memiliki pemahaman yang tercampur dengan miskonsepsi dimana alasan yang diberikan tidak jelas dan menunjukkan ketidaklogisan informasi jika dihubungkan dengan konsep yang diinginkan. Hal ini mengindikasikan bahwa pembelajaran yang terjadi di kelas atau proses pembelajaran yang dialami oleh peserta didik kurang berarti atau bermakna. Peserta didik dalam kasus ini mengetahui jawaban konsep yang benar tanpa mengetahui mengapa konsep tersebut benar (Bayrak, 2013). 


\section{KESIMPULAN}

Dari uraian analisis hasil kajian ditemukan bahwa: (1). Pemahaman konsep peserta didik SMAN 1 Mawasangka Tengah pada materi Gelombang Mekanik termasuk dalam kategori rendah. Peserta didik yang paham konsep sebesar $22,5 \%$, sebagian besar pemahaman peserta didik pada kriteria tidak paham konsep sebesar $14,7 \%$ dan $62,8 \%$ terindikasi mengalami miskonsepsi; (2). Miskonsepsi kategori tinggi ditemukan pada konsep faktor-faktor yang mempengaruhi cepat rambat gelombang sebesar 81,4\%. Miskonsepsi kategori sedang ditemukan pada konsep periode gelombang berjalan sebesar $64,4 \%$ dan Panjang gelombang pada gelombang stasioner sebesar 69,9\%. Sedangkan miskonsepsi kategori rendah ditemukan pada sub konsep frekuensi gelombang berjalan sebesar $51,4 \%$ dan frekuensi pada gelombang stasioner sebesar $48,6 \%$.

Saran untuk peneliti selanjutnya yaitu (1).Sebaiknya dilakukan penelitian lanjutan mengenai penyebab miskonsepsi dan tidak paham konsep, agar hasilnya dapat dijadikan refleksi bagi guru dalam pembelajaran selanjutnya. Serta (2).Perludilakukan pembelajaran remediasi setelah teridentifikasi konsep alternatif siswa agar konsep yang salah dapat tereduksi.

\section{DAFTAR PUSTAKA}

Abraham, M. R. Grzybowski, E. B., Renner, J. W. \& Marek, E. A. (1992). Understanding and Misunderstanding of Eigth Grader of Five Chemistry Concept Found in Textbook. Journal of Research in Science Teaching, 29(2), 105-120.

Bayrak, B. K. (2013). Using Two-Tier Test to Identify Primary Studend's Conceptual Understanding and Alternative Conceptions in Acid Base. Mevlana International Journal of Education, 3(2), 19-26.

Iriyanti, P. N. (2012). Identifikasi Miskonsepsi Pada Materi Pokok Wujud Zat Siswa Kelas VII SMP Negeri 1 Bawang Tahun Ajaran 2009/2010.. Jurnal Pendidikan Kimia, 1(1).
Khairunnisa, K., Ishafit, I., \& Fayanto, S. (2020). Physics Teaching: Development of Lectora Inspire with Multiple-Representation Approach to Reduce of Misconception. Jurnal Dedikasi Pendidikan, 4(2), 159-170.

McClary, L. M., \& Bretz, S. L. (2012). Development and assessment of a diagnostic tool to identify organic chemistry students' alternative conceptions related to acid strength. International Journal of Science Education, 34(15), 2317-2341.

Purwanto. (2013). Evaluasi hasil belajar. Yogyakarta: Pustaka Pelajar.

Suparno, P. (2005). Miskonsepsi \& Perubahan Konsep dalam Pendidikan Fisika. Jakarta: Grasindo.

Suparno, P. (2013) . Miskonsepsi dan Perubahan Konsep Pendidikan Fisika. Jakarta: PT. Grasindo

Susanti , E. H. (2014). Profil miskonsepsi siswa smp kelas viii pada materi getaran, gelombang, dan bunyi. Surakarta: UNS-FKIP

Tiara, V. M. (2018). Efektivitas penggunaan modul pembelajaran fisika berbasis unity of sciences kelas VIII pada materi getaran dan gelombang terhadap hasil belajar peserta didik di MTS NU Banat Kudus (Doctoral dissertation, UIN Walisongo Semarang).

Waluya, B. (2008). Penggunaan Model Pembelajaran Generatif untuk Meningkatkan Pemahaman Siswa pada Konsep Geografi. Jurnal Pendidikan Geografi FPIPS UPI, 2(1), 1-9.

Widiyanto, A., Sujarwanto, E., \& Prihaningtiyas, S. (2018, October). Analisis Pemahaman Konsep Peserta Didik dengan Instrumen Four Tier Diagnostic Test pada Materi Gelombang Mekanik. In Prosiding Seminar Nasional Multidisiplin (Vol. 1, pp. 138146).

Yustiandi, Y., \& Saepuzaman, D. (2017). Profil Kemampuan Interpretasi Grafik Kinematika Siswa SMA Kelas X. Gravity: Jurnal Ilmiah Penelitian dan Pembelajaran Fisika, 3(1). 